\title{
Article \\ Study on the Behavior and Removal of Cadmium and Zinc Using Taraxacum officinale and Gazania under the Application of Biodegradable Chelating Agents
}

\author{
Naoki Kano ${ }^{1, *(D)}$, Takumi Hori ${ }^{2}$, Haixin Zhang ${ }^{2}$, Naoto Miyamoto ${ }^{1}$, David Eva Vanessa Anak ${ }^{1}$ and \\ Kenji Mishima ${ }^{3}$ \\ 1 Department of Chemistry and Chemical Engineering, Faculty of Engineering, Niigata University, Niigata \\ 950-2181, Japan; nmiyamoto@eng.niigata-u.ac.jp (N.M.); t19g923d@mail.cc.niigata-u.ac.jp (D.E.V.A.) \\ 2 Graduate School of Science and Technology, Niigata University, Niigata 950-2181, Japan; \\ takumi.abc1233@gmail.com (T.H.); F19B137H@mail.cc.niigata-u.ac.jp (H.Z.) \\ 3 Center for Computational Sciences, University of Tsukuba, Tsukuba 305-8577, Japan; \\ mishima.kenji.fu@u.tsukuba.ac.jp \\ * Correspondence: kano@eng.niigata-u.ac.jp; Tel.: +81-025-262-7218
}

check for

updates

Citation: Kano, N.; Hori, T.; Zhang, H.; Miyamoto, N.; Anak, D.E.V.;

Mishima, K. Study on the Behavior and Removal of Cadmium and Zinc Using Taraxacum officinale and Gazania under the Application of Biodegradable Chelating Agents. Appl. Sci. 2021, 11, 1557. https:// doi.org/10.3390/app11041557

Academic Editor: Federica Spina

Received: 5 January 2021

Accepted: 4 February 2021

Published: 9 February 2021

Publisher's Note: MDPI stays neutral with regard to jurisdictional claims in published maps and institutional affiliations.

Copyright: (c) 2021 by the authors. Licensee MDPI, Basel, Switzerland. This article is an open access article distributed under the terms and conditions of the Creative Commons Attribution (CC BY) license (https:// creativecommons.org/licenses/by/ $4.0 /)$.

\begin{abstract}
The removal of cadmium (Cd) and zinc ( $\mathrm{Zn}$ ) from soil by phytoremediation was investigated using Taraxacum officinale and Gazania. A plant environmental control system was used to cultivate the plants. The effects of different biodegradable chelating agents (i.e., EDDS, HIDS, and GLDA), relative humidity, and other competitive metals on the adsorption of $\mathrm{Cd}$ and $\mathrm{Zn}$ were also studied. In addition, the approach for metal recovery was explored by extraction of metals from plants after phytoremediation using Gazania. The concentrations of $\mathrm{Cd}$ and $\mathrm{Zn}$ were determined by inductively coupled plasma mass spectrometry (ICP-MS). In addition, one-way analysis of variance (ANOVA) tests were performed.to determine significant differences between the experimental treatments adopted in this work. Consequently, the following main conclusions were obtained: (1) In the case of Taraxacum officinale, $\mathrm{Cd}$ and $\mathrm{Zn}$ could be removed even under the presence of other heavy metals. (2) By adding a chelating agent, the amount absorbed by the shoot generally increased. (3) In the case of Gazania, the concentration of Cd was higher in root than that in shoot, whereas the concentration of $\mathrm{Zn}$ was higher in the shoot than that in the root. (4) Taraxacum officinale was more suitable for phytoremediation of Cd than Gazania. (5) $\mathrm{Cd}$ and $\mathrm{Zn}$ could be extracted from plants by adding a low concentration of nitric acid. (6) The one-way ANOVA tests showed no statistically significant differences among the experimental treatments.
\end{abstract}

Keywords: phytoremediation; cadmium; zinc; biodegradable chelating agent; one-way ANOVA; metal recovery

\section{Introduction}

Soil pollution is becoming more and more serious with the rapid development of industry, sewage sludge disposal, metal processing, and energy production. Hence, it is important and urgent to remediate polluted soil. The conventional remediation methods such as the replacement of contaminated soil with clean soil, are usually expensive and intrusive to the ecosystem [1]. The phytoremediation of heavy metals, which has the advantages of being low-cost and environmentally-friendly and resulting in minimal soil disturbance, has attracted more and more interest in recent years [2-5]. Heavy metals are of major environmental concern because they are non-biodegradable, and thus persist almost indefinitely in the environment. Cadmium $(\mathrm{Cd})$ is one of the most toxic heavy metals, which has been classified as a human carcinogen and teratogen [6]. It is the byproduct of zinc mining, where it is found as cadmium sulfide [7]. Cd accumulates mainly in the kidneys and liver in humans and can cause many diseases such as hypertension, diarrhea, and stomach pains $[8,9]$. 
Phytoremediation makes use of the harvestable part of the plants to remove pollutants. Any plants can theoretically uptake metals from the soil; however, the overwhelming majority of plants generally remove only a small percentage of heavy metals from contaminated soil due to their low biomass and/or weak translocation from root to shoot. Therefore, using plants with high biomass yields, along with adding chemically enhanced agents, has been widely applied as a viable strategy for removing heavy metals from soils over a reasonable time frame [10-12]. In this study, two kinds of plants (i.e., Taraxacum officinale and Gazania) were investigated based on a report of the effectiveness of phytoremediation of Cd by Asteraceae plants [13]. It is known that Gazania can grow wild naturally without depending on the soil environment. Thus, it is considered that Gazania can accumulate a large amount of $\mathrm{Cd}$ at the shoot because its flowering time is long. Meanwhile, Taraxacum officinale is a relatively imminent plant with longer roots in which higher amounts of nourishment can be stored, which can be expected to accumulate a lot of $C d$. In this work, zinc $(\mathrm{Zn})$ was also selected as a subject element because $\mathrm{Zn}$ pollution is known to occur at the same time near mined land where $\mathrm{Cd}$ pollution takes place.

The objective of this research was, first, to confirm the effectiveness of Taraxacum officinale and Gazania for the phytoremediation of $\mathrm{Cd}$ and $\mathrm{Zn}$ by applying biodegradable chelating agents. Generally, it is well known that ethylene-diamine-tetraacetic acid disodium salt (EDTA) is as an effective chelating agent for assisting phytoremediation by enhancing the mobility of metals in soil (e.g., [14,15]). However, it has been suggested that EDTA is a potential risk to groundwater and drinking water due to its remobilization of metals from sediments and soil $[16,17]$. In order to reduce the potential environmental risk of EDTA, an easily biodegradable chelating agent, namely, $(\mathrm{S}, \mathrm{S})$ - ethylenediamine$\mathrm{N}, \mathrm{N}^{\prime}$-disuccinic acid trisodium salt (EDDS), was used as a substitute for EDTA in this work based on previous literatures [18,19]. In addition to EDDS, 3-hydroxy-2,2'-iminodisuccinic acid, sodium (HIDS) and N,N-dicarboxymethyl glutamic acid (GLDA) were also used as biodegradable chelating agents. Furthermore, another purpose was to ascertain if the effect of the phytoremediation varies with the type and amount of added chelating agent. The translocation factor from root to shoot, as well as the amount of uptake, were also studied to determine which chelator represents the most effective tool for the efficient phytoremediation of $\mathrm{Cd}$ and $\mathrm{Zn}$.

It is also important to investigate the disposal method of plants after phytoremediation. Thus far, plants containing heavy metals have been generally subjected to incineration disposal [20]. However, it is desirable to recover and reuse the adsorbed materials from an industrial and technological point of view. Then, extraction experiments of $\mathrm{Cd}$ and $\mathrm{Zn}$ from plants after phytoremediation were also conducted in this work using different reagents (acid or base) to develop the effective utilization of the plants and the reutilization of treatment waste liquid for a preliminary approach for metal recovery from plant tissues.

It should be stressed that the original purpose of our extraction studies is to investigate the effective utilization of the plant including metals for a future search of the utilization of metal resources. This aim is considerably different form other similar experiments reported so far.

\section{Materials and Methods}

\subsection{Preparation of $\mathrm{Cd}$ - and $\mathrm{Zn}$-Contaminated Soil}

The contaminated soil used in the present study was prepared by adding a solution containing two kinds of metallic salts (i.e., $\mathrm{Cd}\left(\mathrm{NO}_{3}\right)_{2}\left(5 \mathrm{mmol} \mathrm{kg}{ }^{-1}\right)$ and $\mathrm{Zn}\left(\mathrm{NO}_{3}\right)_{2} \cdot 6 \mathrm{H}_{2} \mathrm{O}$ $\left.\left(5 \mathrm{mmol} \mathrm{kg}{ }^{-1}\right)\right)$ into "expanded vermiculite" soil based on the literature [21,22]. The soil was purchased commercially from Takamura Co. Ltd. (Otawara City, Tochigi, Japan), which has high moisture retention capability, air capacity, and nutrient preserving capability. The physical and chemical characteristics of the expanded vermiculite were as follows: $\mathrm{pH}\left(\mathrm{H}_{2} \mathrm{O}\right), \mathrm{pH}(\mathrm{KCl})$ and $\mathrm{EC}$ (Electric Conductivity) in the soil are 7.20, 5.17 and $23.8\left(\mu \mathrm{S} \cdot \mathrm{cm}^{-1}\right)$ respectively. In addition, Moisture content $(\%)$, Organic matter content $(\%)$ and CEC $\left(\mathrm{cmol} \cdot \mathrm{kg}^{-1}\right)$ in the soil were $0.241,1.40$ and 11.5 respectively. The measurement 
methods of these characteristics are the same as shown in our previous paper [23]. The $\mathrm{Cd}\left(\mathrm{NO}_{3}\right)_{2}$ and $\mathrm{Zn}\left(\mathrm{NO}_{3}\right)_{2} \cdot 6 \mathrm{H}_{2} \mathrm{O}$ were purchased from Kanto Chemical Co., Inc. (Tokyo, Japan).

\subsection{Cultivation and Apparatus for Phytoremediation}

For the plants, Taraxacum officinale and Gazania were used in this work. These germinated plants were transferred to separate pots containing $100 \mathrm{~g}$ of $\mathrm{Cd}$ and $\mathrm{Zn}$-contaminated soil, as shown in Table 1. The contaminated soil was used to fill $500 \mathrm{~mL}$ plastic pots and moistened with ultrapure water to reach an approximately $80 \%$ water holding capacity. A plant environmental control system (LPH-220N, Nippon Medical \& Chemical Instruments Co. LTD, Osaka, Japan) was used to cultivate the plants. The growing conditions in the plant environmental control system were as follows. We set simulated Day $(12 \mathrm{~h}$, Temperature: $27^{\circ} \mathrm{C}$, Relative humidity: $70 \%$, Photon flux density: 7500 lx) and Night (12 h, Temperature: $22{ }^{\circ} \mathrm{C}$, Relative humidity: $70 \%$, Photon flux density: 0 lx) in a plant environmental control system in our work.

Table 1. Conditions of the pot experiments.

\begin{tabular}{cccccccc}
\hline Pot No. & $\mathbf{1}$ & $\mathbf{2}$ & $\mathbf{3}$ & $\mathbf{4}$ & $\mathbf{5}$ & $\mathbf{6}$ & $\mathbf{7}$ \\
\hline Cd and Zn (mg/kg soil) & - & 6.5 & 6.5 & 6.5 & 6.5 & 6.5 & 6.5 \\
EDDS (mmol/kg soil) & - & - & 0.5 & 1 & 3 & 5 & 7 \\
\hline "-" means no addition $^{-1}$
\end{tabular}

\subsubsection{Effect of EDDS on the Adsorption of Cd and Zn}

The plants were harvested in 3 weeks followed by treatments of EDDS, which was purchased from Sigma-Aldrich, Inc. (Darmstadt, Germany). In this study, EDDS was added at $0.5,1,3,5$, and $7 \mathrm{mmol} \mathrm{kg}^{-1}$ to the soil in Pot Nos. 3-7, respectively, as shown in Table 1. In contrast, no chelators were added to Pot No. 2 (contaminated by Pb and Zn) or Pot No. 1 (without contamination), which were kept as a control and as a blank, respectively (Table 1). The application of chelating agents such as EDDS was based on previous papers $[24,25]$.

\subsubsection{Effect of Relative Humidity on the Adsorption of $\mathrm{Cd}$ and $\mathrm{Zn}$}

Relative humidity is one of the parameters that can influence the growing of plants $[26,27]$. In order to investigate the effect of relative humidity on the adsorption of $\mathrm{Cd}$ and $\mathrm{Zn}$ by these plants, an experiment under $50 \%$ relative humidity conditions was also conducted. The other experimental conditions were the same as that in Section 2.2.1.

\subsubsection{Effect of Other Competitive Metals on the Adsorption of $\mathrm{Cd}$ and $\mathrm{Zn}$}

The effect of other competitive metals on the extraction of the subject elements is also important [28]. Secondary to the former experiments for investigating the tolerance of Taraxacum officinale and Gazania against $\mathrm{Cd}$ and $\mathrm{Zn}$, the effect of competitive metals (i.e., $\mathrm{Al}, \mathrm{Pb}, \mathrm{Bi}$, and $\mathrm{Ni}$ ) on the adsorption of $\mathrm{Cd}$ and $\mathrm{Zn}$ was also studied. The experiment was carried out under $50 \%$ relative humidity conditions, and the other conditions of each pot in this experiment are shown in Table 2.

Table 2. Conditions of the pot experiments under the presence of other competitive metals.

\begin{tabular}{cccccccc}
\hline Pot No. & $\mathbf{1}$ & $\mathbf{2}$ & $\mathbf{3}$ & $\mathbf{4}$ & $\mathbf{5}$ & $\mathbf{6}$ & $\mathbf{7}$ \\
\hline $\mathrm{Cd}, \mathrm{Zn}(\mathrm{mg} / \mathrm{kg}$ soil) & 6.5 & 6.5 & 6.5 & 6.5 & 6.5 & 6.5 & 6.5 \\
$\mathrm{Al}, \mathrm{Pb}, \mathrm{Bi}$, and Ni & - & 6.5 & 6.5 & 6.5 & 6.5 & 6.5 & 6.5 \\
$\quad(\mathrm{mg} / \mathrm{kg}$ soil) & - & - & 0.5 & 1 & 3 & 5 & 7 \\
EDDS (mmol/kg soil) & &
\end{tabular}

"s" means no addition. 


\subsubsection{Effect of Chelating Agents on the Adsorption of $\mathrm{Cd}$ and $\mathrm{Zn}$}

In order to compare the effect among the chelating agents on the adsorption of $\mathrm{Cd}$ and Zn, HIDS and GLDA were also used in this work, in addition to EDDS. HIDS and GLDA were supplied by Nippon Shokubai (Osaka, Japan) and Tokyo Kasei (Tokyo, Japan) respectively. The structure of each biodegradable chelating agent is shown in Figure 1. The experiment was carried out under $50 \%$ relative humidity conditions, and the other conditions of each pot in this experiment are shown in Table 3.

(a)<smiles>O=C(O)CC(NCCNC(CC(=O)O)C(=O)O)C(=O)O</smiles>

(b)<smiles>[N+]O[N+](=O)CC(NC(C(=O)O)C(O)C(=O)O[Na])C(=O)O[Na]</smiles>

(c)<smiles>O=C(O)CCC(C(=O)O)N(CC(=O)O)CC(=O)O</smiles>

Figure 1. The structure of each chelating agent: (a) EDDS; (b) HIDS; (c) GLDA.

Table 3. Conditions of the pot experiments using different kinds of chelating agents.

\begin{tabular}{ccccccccc}
\hline Pot No. & $\mathbf{1}$ & $\mathbf{2}$ & $\mathbf{3}$ & $\mathbf{4}$ & $\mathbf{5}$ & $\mathbf{6}$ & $\mathbf{7}$ & $\mathbf{8}$ \\
\hline Cd and Zn (mg/kg soil) & 6.5 & 6.5 & 6.5 & 6.5 & 6.5 & 6.5 & 6.5 & 6.5 \\
Al, Pb, Bi, and Ni & - & 6.5 & 6.5 & 6.5 & 6.5 & 6.5 & 6.5 & 6.5 \\
$\quad$ (mg/kg soil) & & & EDDS & EDDS & HIDS & HIDS & GLDA & GLDA \\
$\begin{array}{c}\text { Chelating agents } \\
\text { (mmol/kg soil) }\end{array}$ & - & - & 1 & 5 & 1 & 5 & 1 & 5 \\
\hline “-" means no addition. & & & & & & & &
\end{tabular}

"-" means no addition.

\subsection{Sample Preparation and Analysis}

After 3 weeks growth, the plants were harvested and the above-ground (i.e., shoots) and below-ground (i.e., roots) parts were separated. The shoot and root samples were washed carefully with ultrapure water after tap water to remove any soil splash, were oven-dried at $80{ }^{\circ} \mathrm{C}$ for $24 \mathrm{~h}$, and were then ground in a mortar. Dried plant samples $\left(0.1 \mathrm{~g}\right.$ of each sample) were digested with $10 \mathrm{~cm}^{3}$ conc. $\mathrm{HNO}_{3}(61 \%)$ and $3.0 \mathrm{~cm}^{3}$ conc. $\mathrm{HF}$ $(46 \%)$ in a microwave digestion system (Speedwave4, ACTAC. Co. LTD, Tokyo, Japan). The digested samples were diluted to $100 \mathrm{~mL}$, then $\mathrm{Cd}$ and $\mathrm{Zn}$ were determined by Inductively Coupled Plasma Mass Spectrometry (ICP-MS, Thermo Fisher Scientific, Xseries II, Massachusetts, USA) [29]. Replicate experiments were basically performed three times. The operating conditions of ICP-MS are shown in Supplementary Materials Table S1. The $\mathrm{Cd}$ and $\mathrm{Zn}$ standard solutions used for making the calibration curve were prepared by diluting the standard solutions $\left(1000 \mathrm{mg} / \mathrm{L}\right.$ in $6 \% \mathrm{HNO}_{3}$ solution). All of the chemical reagents used were of analytical grade. Water $(>18.2 \mathrm{M} \Omega)$, which was treated by an ultrapure water system (Advantec Aquarius: RFU 424TA), was used throughout the work. The translocation factor from root to shoot was also calculated by dividing the metal concentration in the shoot by that in the root $[30,31]$.

The surface morphology and element distribution of the roots and shoots of Taracum officinale after cultivation were investigated using Scanning Electron Microscope and Energy Dispersive Spectrometer (SEM-EDS, JEOL, Akishima City, Tokyo, Japan: JCM-6000 with JED-2300).

\subsection{Extraction of $\mathrm{Cd}$ and $\mathrm{Zn}$ from Gazania after Phytoremediation: An Approach for Metal Recovery from Plant Tissues}

To realize the original purpose of our extraction studies mentioned in Introduction, extraction experiments of Cd and Zn from Gazania after phytoremediation were conducted. In each extraction experiment, the spent plant was accurately weighed to $0.1 \mathrm{~g}$ into an Erlenmeyer flask containing $100 \mathrm{~mL}$ extractant solvent, and then heated in a water bath at 
$60{ }^{\circ} \mathrm{C}$ for $1 \mathrm{~h}$. Then, the mixed solution was filtered with a $0.45 \mu \mathrm{m}$ membrane filter, and the heavy metal ( $\mathrm{Cd}$ or $\mathrm{Zn}$ ) content in the filtrate was determined by ICP-MS.

\subsubsection{Effect of the Extractant Solvent on the Extraction of $\mathrm{Cd}$ and $\mathrm{Zn}$ from Gazania}

In order to investigate the effect of the extractant solvent on the extraction of $\mathrm{Cd}$ and $\mathrm{Zn}$ from Gazania, several kinds of solvents (i.e., $\mathrm{CH}_{3} \mathrm{COOH}, \mathrm{HNO}_{3}, \mathrm{H}_{2} \mathrm{SO}_{4}, \mathrm{H}_{3} \mathrm{PO}_{4}, \mathrm{NH}_{3}$, and $\mathrm{NaOH})$ at different concentrations i.e., $(0.18,0.36,1.8$, or $3.6 \mathrm{~mol} / \mathrm{L})$ were employed.

\subsubsection{Extraction Experiment Using Incineration Ash from Gazania}

The spent plant was incinerated using an electric furnace at 200,400 , and $600{ }^{\circ} \mathrm{C}$. The above extraction experiment was performed using these incineration ashes. The experimental conditions were the same as that in Section 2.4.1.

\subsection{Statistics Analysis: Analysis of Variance (ANOVA)}

The one-way ANOVAs presented in Section 3.3 were performed in Excel [32] and used to determine significant differences among experimental treatments. To test data normality, we employed the chi-squared type goodness-of-fit test. In addition, Levene's test was used to check data homogeneity. Finally, Tukey-Kramer post hoc test in Excel was performed.

\section{Results and Discussion}

3.1. Phytoremediation of $C d$ and $\mathrm{Zn}$ by Taracum officinale

3.1.1. Effect of EDDS on the Adsorption of Cd and Zn

The concentrations of heavy metals in the shoots or roots of Taraxacum officinale $(\mathrm{mg} / \mathrm{kg}$ plant) in all pots by adding various concentrations of EDDS after 3 weeks of growth are shown in Figure 2a for $\mathrm{Cd}$ and Figure $2 \mathrm{~b}$ for $\mathrm{Zn}$. By comparing the data in Figure 2a, it can be found that adding more EDDS (i.e., Pot Nos. 6 and 7 when adding 5 or $7 \mathrm{mmol} \mathrm{kg}{ }^{-1}$ of EDDS) significantly enhanced the concentrations of $\mathrm{Cd}$ both in the shoot and in the root. On the other hand, the concentrations of $\mathrm{Zn}$ are not largely varied, although those in Pot No. 5 when adding $3 \mathrm{mmol} \mathrm{kg}-1$ EDDS is the highest.

The translocation factor (TF) from root to shoot was calculated by dividing the metal concentration of the shoot by that of the root:

$$
\mathrm{TF}=\mathrm{C}_{\text {shoot }} / \mathrm{C}_{\text {root }}
$$

The TFs of $\mathrm{Cd}$ and $\mathrm{Zn}$ in Taraxacum officinale are shown in Figure 3. As can be observed in Figure 3, the TF increased by adding EDDS, which is particularly remarkable in the case of $1 \mathrm{mmol} \mathrm{kg}^{-1}$ of EDDS for Cd. However, as for $\mathrm{Zn}$, a large increase in TF was not observed, although the value was high when adding $0.5-3 \mathrm{mmol} \mathrm{kg}-1$ of EDDS compared to no addition. This suggests that Taraxacum officinale is more tolerant toward low concentrations ( 0.5 or $1 \mathrm{mmol} / \mathrm{kg}$ soil) of EDDS, as well as heavy metals (Cd and $\mathrm{Zn}$ ), considering the biomass of each shoot or root under the presence of EDDS, as shown in Table S2, although high concentrations of EDDS may result in a decrease of biomass.

It is known that the biomass decreases by adding a chelating agent such as EDTA for the phytoremediation of $\mathrm{Cd}, \mathrm{Pb}$, and $\mathrm{Cu}$ [33]. This may be due to the increase in heavy metal solubility, as well as the toxicity of EDTA. In this work, the amount of Cd uptaken increased as the concentration of EDDS increased. Therefore, it is considered that the biomass or TF showed small values under high EDDS concentrations in this study.

Wang et al. [34] described that the interaction pattern of $\mathrm{Cd}$ and $\mathrm{Zn}$ shows an antagonistic behavior under the combined treatment of low concentrations of $\mathrm{Cd}$ and $\mathrm{Zn}$ (while it shows a synergistic behavior under the combined treatment of high concentrations of $\mathrm{Cd}$ and $\mathrm{Zn}$ ). It is known that the pathways of the uptake and transport of $\mathrm{Cd}$ and $\mathrm{Zn}$ in plants are similar in nature because of the similarities in their physical and chemical characteristics. However, plants have cleverly developed to react to $\mathrm{Cd}$ and $\mathrm{Zn}$ stresses adequately enough to prevent the damage induced by $\mathrm{Cd}$ and to maintain $\mathrm{Zn}$ homeostasis [35]. However, these reactions have been found to depend on the species, external bioavailable metal 
concentration, tissue type, and developmental stage. It has been suggested that $\mathrm{Zn}$ and $\mathrm{Cd}$ homeostasis mechanisms in plants consist of a common pathway.
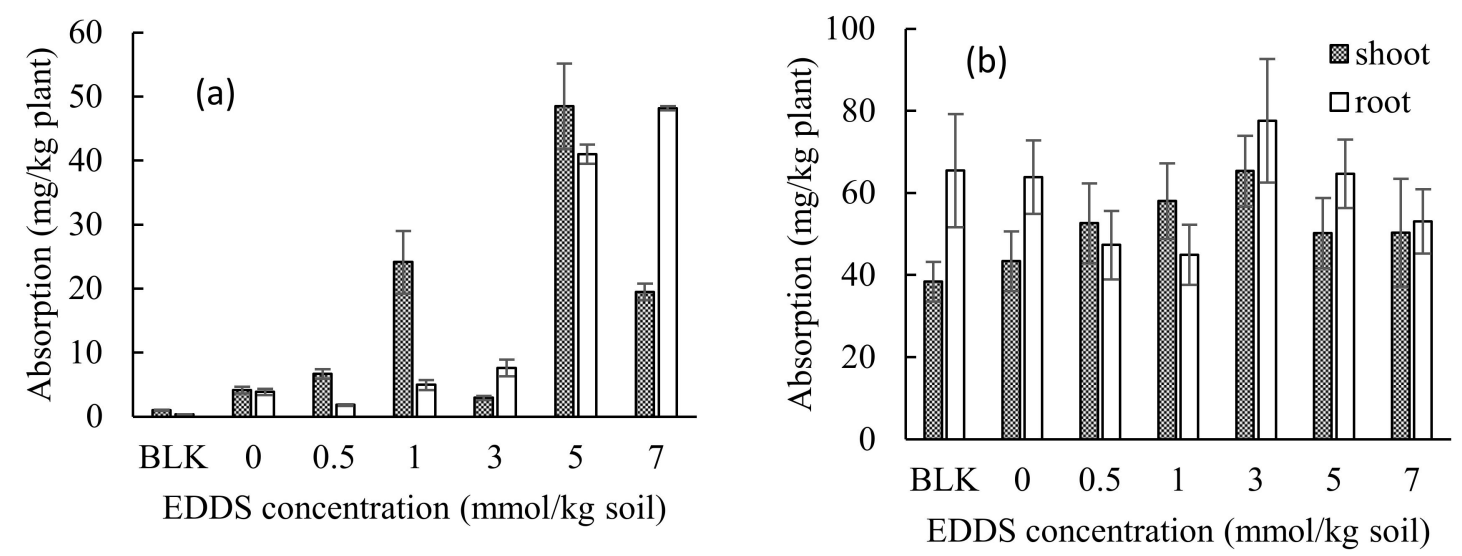

Figure 2. Effect of the EDDS concentration on the adsorption of (a) Cd (b) Zn by Taracum officinale (70\% humidity). BLK represents the pot for no addition of heavy metals (i.e., $\mathrm{Cd}$ and $\mathrm{Zn}$ ) as well as no addition of EDDS (i.e., Pot No. 1 in Table 1).

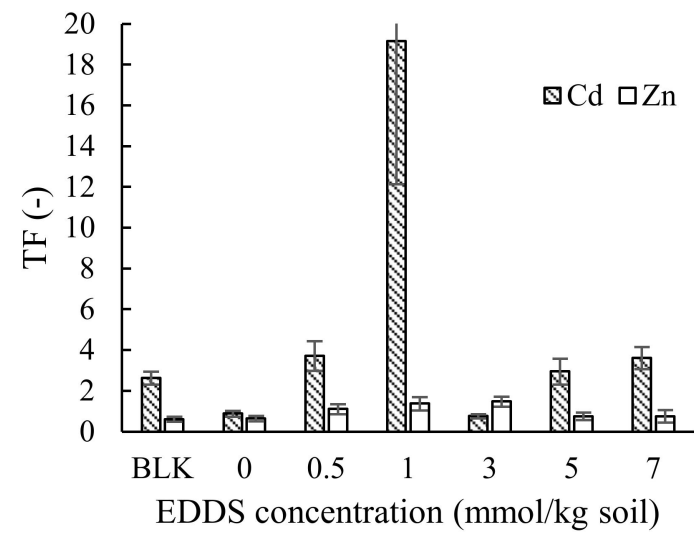

Figure 3. Effect of the EDDS concentration on the translocation factor (TF) of Cd and Zn in Taraxacum officinale (70\% humidity). BLK represents the pot for no addition of heavy metals (i.e., $\mathrm{Cd}$ and $\mathrm{Zn}$ ) as well as no addition of EDDS (i.e., Pot No. 1 in Table 1).

When heavy metals present in equal amounts in the geochemical background of soil systems, they do not disrupt the soil metabolism or plant growth. Moreover, $\mathrm{Zn}$ has been used in the biochemistry of land plants and its homeostasis is maintained by a tightly regulated network of low-molecular-weight ligands, membrane transport, Zn-binding proteins, and regulators. In its oxidized form, Zn functions as a catalytic or structural cofactor in a large number of enzymes and regulatory proteins [36]. In contrast, $\mathrm{Cd}$ is a non-essential and non-metabolic heavy metal, and its proper functioning in the soil system has not been proven yet.

Plants cultivated on soil with elevated amounts of heavy metals generally show signs of inhibited growth, limited germination of seeds, and deformation of roots. These effects can be clearly observed during the early stage of plant development. When the concentration of metals in the soil system increases, synthesis of phytochelatins in the plants is induced. The main function of these proteins is to sustain the homeostasis of metals in the cell. This activity is disrupted when excessive amounts of $\mathrm{Cd}$ and $\mathrm{Zn}$ are added into the soil, as they interfere with the control mechanisms of the plants and, as a result, enzymatic protein activity is inhibited [37].

The insufficient uptake of $\mathrm{Zn}$ compared to $\mathrm{Cd}$ (and the competition) found in our work may be attributed to the differences in homeostasis mechanisms between the two heavy metals. 
EDDS, HIDS, and GLDA have ligands and functional group as shown in Figure 1. For instance, the stability constants of EDDS with $\mathrm{Cd}^{2+}$ and $\mathrm{Zn}^{2+}$ are $10^{11.5}$ and $10^{13.5}$, respectively, whereas those of EDTA with $\mathrm{Cd}^{2+}$ and $\mathrm{Zn}^{2+}$ are $10^{16.5}$ and $10^{16.5}$, respectively) [38], which is also cited in Table S3. The stability constant of EDDS is still considered as a high value, although having a lower value of stability constant compared to EDTA. Hence, it is considered that the biodegradable chelating agents used in this work had also enhanced the mobility of metal ions from the soil due to the formation of complexes. In other words, we made an inference that these ligands have high metal ion binding abilities too.

\subsubsection{Effect of Relative Humidity on the Adsorption of $\mathrm{Cd}$ and $\mathrm{Zn}$}

The concentrations of heavy metals in the shoots or roots of Taraxacum officinale in all of the pots under a relative humidity of 50\% are shown in Figure S1a for Cd and Figure S1b for $\mathrm{Zn}$, while the TFs are shown in Figure S2. When comparing the $50 \%$ and $70 \%$ relative humidity conditions, the uptake of $\mathrm{Cd}$ and the TF of $\mathrm{Cd}$ was generally higher under the $50 \%$ relative humidity conditions. It has been reported that transpiration speed in a plant becomes faster when humidity decreases [39]. Then, the movement of water from the root to shoot may be activated, and the translocation of $\mathrm{Cd}$ is promoted. Furthermore, it is noteworthy that the concentration of $\mathrm{Cd}$ in the shoot is larger than that in the root under the relative humidity of both $50 \%$ and $70 \%$. Li et al. [40] reported that $\mathrm{Cd}$ is accumulated more in the roots than in the shoots. Therefore, it was considered that the translocation of $\mathrm{Cd}$ from the roots to shoots was promoted by adding EDDS in our experiment. However, a significant difference was not observed between the relative humidity of $50 \%$ and that of $70 \%$ in the case of the TF of $\mathrm{Zn}$. This may be also related to the completive translocation between the two heavy metals. Considering the above-mentioned situation, it may be difficult to translocate both $\mathrm{Cd}$ and $\mathrm{Zn}$ simultaneously by Taraxacum officinale, even if EDDS is added. Moreover, it has been suggested that humidity can be one of the important factors impacting the adsorption of metals by phytoremediation.

\subsubsection{Effect of Other Competitive Metals on the Adsorption of $\mathrm{Cd}$ and $\mathrm{Zn}$}

The concentrations of $\mathrm{Cd}$ and $\mathrm{Zn}$ in the shoots or roots of Taraxacum officinale under the presence of other competitive metals (i.e., $\mathrm{Al}, \mathrm{Pb}, \mathrm{Bi}$, and $\mathrm{Ni}$ ) by adding various concentrations of EDDS are shown in Figure $4 \mathrm{a}$ for $\mathrm{Cd}$ and in Figure $4 \mathrm{~b}$ for $\mathrm{Zn}$, and each of the TF values are shown in Figure S2.
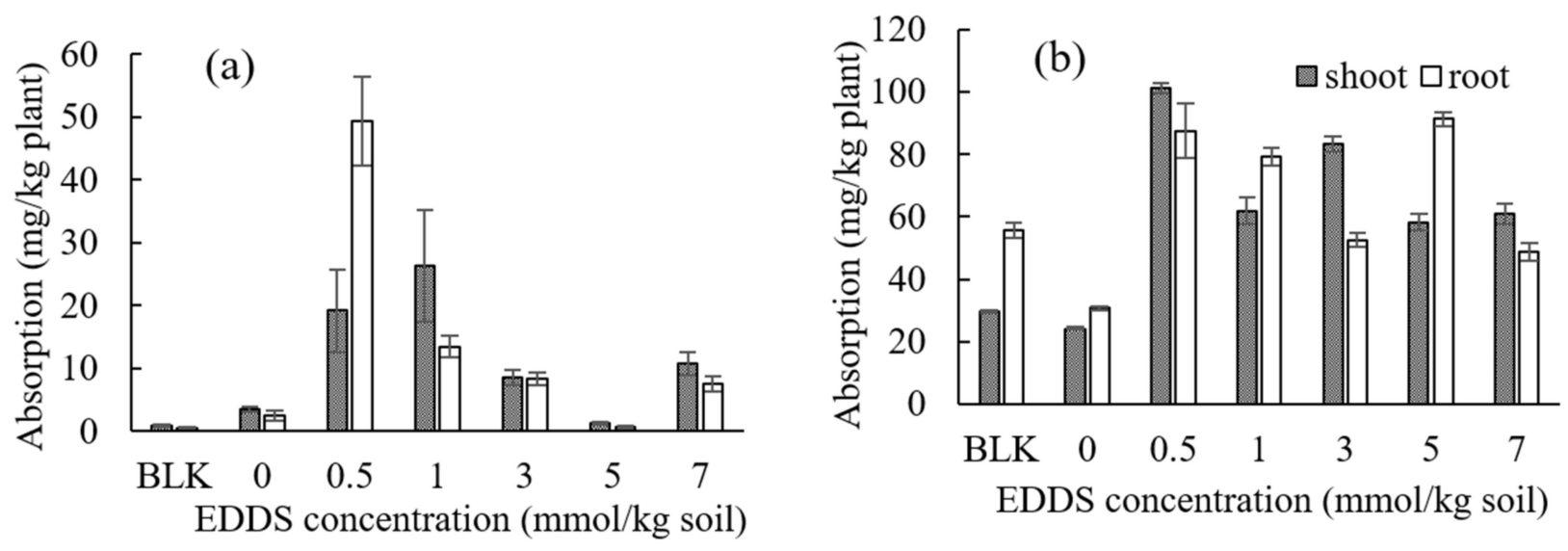

Figure 4. Effect of the EDDS concentration on the absorption of (a) $\mathrm{Cd}$ and (b) $\mathrm{Zn}$ by Taraxacum officinale under the presence of $\mathrm{Al}, \mathrm{Bi}, \mathrm{Ni}$, and $\mathrm{Pb}$. BLK (Blank) represents the pot for no addition of heavy metals (i.e., $\mathrm{Al}, \mathrm{Pb}, \mathrm{Bi}$, and $\mathrm{Ni}$ ) as well as no addition of EDDS (i.e., Pot No. 1 in Table 2).

In Figure 4, it can be seen that the concentrations of $\mathrm{Cd}$ or $\mathrm{Zn}$ did not necessarily decrease under the presence of other competitive metals (i.e., $\mathrm{Al}, \mathrm{Pb}, \mathrm{Bi}$, and $\mathrm{Ni}$ ). Comparing these results with that of Figure S1 (i.e., the case under the absence of other competitive 
metals), the effect of competition with other metals on the concentrations of $\mathrm{Cd}$ or $\mathrm{Zn}$ was not constant and may also depend on the concentration of EDDS. In addition, from Figure S3, it can be concluded that the value of TF is generally higher than unity, although no large increase was observed compared to the case of the absence of other competitive metals (i.e., Figure S3). It can be said that the effect of phytoremediation of $\mathrm{Cd}$ and $\mathrm{Zn}$ by Taraxacum officinale was detected under the presence of the same concentration of other competitive metals (i.e., $\mathrm{Al}, \mathrm{Pb}, \mathrm{Bi}$, and $\mathrm{Ni}$ ) to some extent. Comparing Pot Nos. 1 and 2 in Table S2 under the condition of Table 2, the biomass of the shoots (or roots) increased by adding other competitive metals (i.e., $\mathrm{Al}, \mathrm{Bi}, \mathrm{Ni}$, and $\mathrm{Pb}$ ).

In Wang et al.'s work [34], it was reported that multi-contaminated conditions of soil promote the uptake of heavy metals by the plant. A similar tendency was detected in this work.

As mentioned in Section 3.1.1, the stability constants of EDDS with $\mathrm{Cd}^{2+}$ and $\mathrm{Zn}^{2+}$ are $10^{11.5}$ and $10^{13.5}$, respectively, which are relatively high. Looking at the results from the experiments, we considered that there is not so large selectivity, although EDDS has a higher stability constant with $\mathrm{Zn}^{2+}$ compared to $\mathrm{Cd}^{2+}$ (unlike the case of stability constant for EDTA). In the case of other metals, the stability constants of EDTA with $\mathrm{Pb}^{2+}$ and $\mathrm{Ni}^{2+}$ are known to $10^{18.0}$ and $10^{18.4}$, respectively [41]. This shows that its stability with $\mathrm{Cd}^{2+}$ and $\mathrm{Zn}^{2+}$ is either equal or slightly larger. In this way, it is considered that that chelating agents generally have high stability constant and lower selectivity with any metals.

From our experiments, it may be certainly suggested that the amount of $\mathrm{Cd}$ and $\mathrm{Zn}$ taken up and transported by plants is not affected by the presence of other investigated metal ions in the soil. As mentioned above, it can be said that the chelating ligands bind these metal ions as well. Estimating from the setting condition shown in Table 1 or Table 2 and the molecular weight of chelating agent (for example, that of EDDS is 292.24), the concentration ratio of metal ions to ligand is quite small (that is from $1 / 300$ to $1 / 50$ ), and it can be said that the ligand concentration is much higher than the metal ion concentration; hence, the results obtained from our experiments are considered to be reasonable.

\subsubsection{Effect of Chelating Agents on the Adsorption of $\mathrm{Cd}$ and $\mathrm{Zn}$}

The concentrations of $\mathrm{Cd}$ and $\mathrm{Zn}$ in the shoots or the roots of Taraxacum officinale by adding three types of biodegradable chelating agents at a concentration of 1 or $5 \mathrm{mmol} \mathrm{kg}^{-1}$ are shown in Figure 5a for Cd and Figure 5b for Zn.
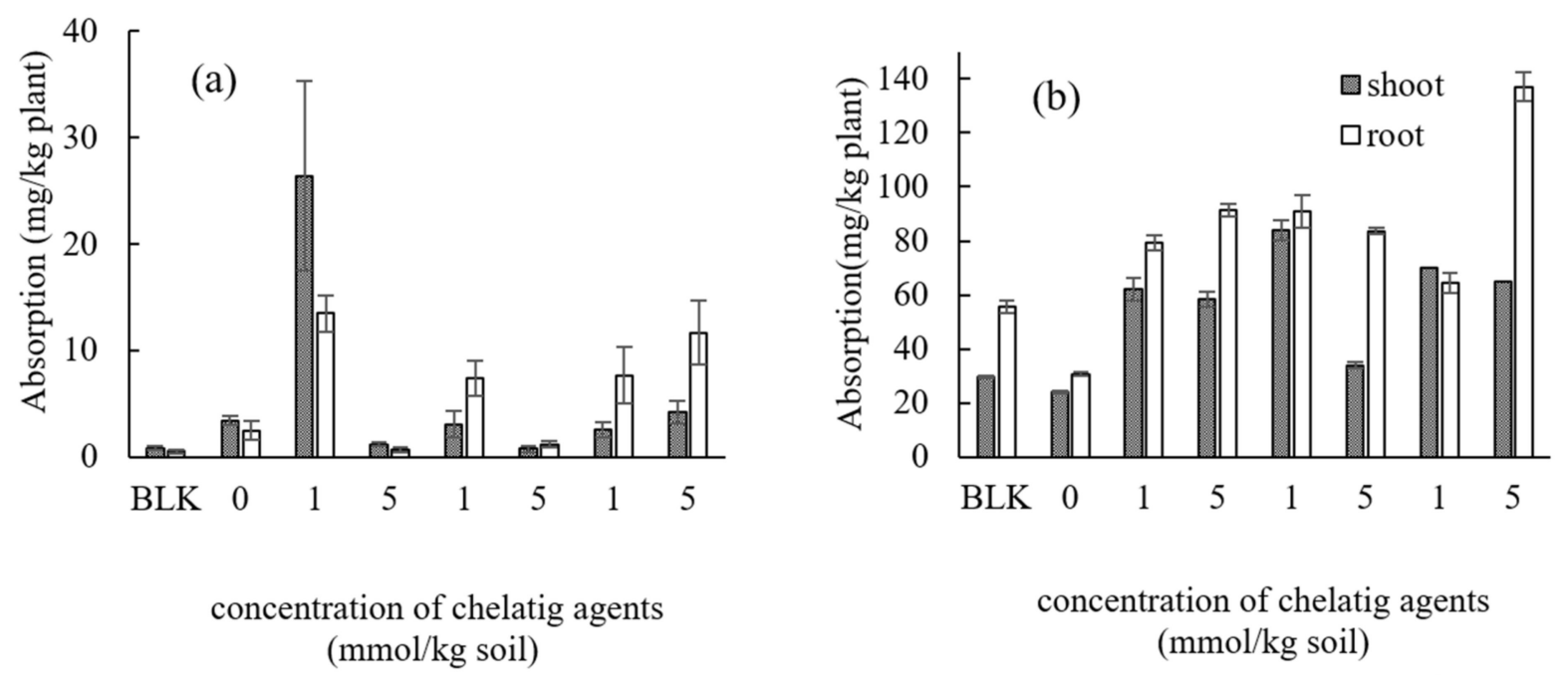

Figure 5. Effect of types and concentrations of chelating agents on the absorption of (a) Cd (b) Zn in Taraxacum officinale. The numbers represent the concentration $\left(\mathrm{mmol} \mathrm{kg}^{-1}\right)$. BLK represents the pot for no addition of heavy metals (i.e., $\mathrm{Al}$, $\mathrm{Pb}$, $\mathrm{Bi}$, and $\mathrm{Ni}$ ) as well as no addition of chelating agents (i.e., Pot No. 1 in Table 3). 
Several previous publications have demonstrated the effectiveness of chelating agents in significantly increasing the uptake of heavy metals [42,43]. For example, the addition of EDTA significantly increases the accumulation of $\mathrm{Zn}$ in sunflower plants (Helianthus annus L.) [42]. Dipu et al. [43] concluded that the uptake of $\mathrm{Pb}$ and $\mathrm{Cu}$ by aquatic plants (Typha sp., Eichhornia sp., and Azolla sp.) is enhanced when EDTA is introduced into the contaminated system. In the case of Cd uptake, EDDS at a concentration of $1 \mathrm{mmol} \mathrm{kg}^{-1}$ is most effective for shoots, whereas adding low concentrations of chelating agents is appropriate (except for GLDA at a concentration of $5 \mathrm{mmol} \mathrm{kg}^{-1}$ ) for roots. Meanwhile, the uptake of Zn was enhanced just by adding a chelating agent, regardless of the kind or concentrations, for both the shoots and roots, which particularly significantly increased in the roots by adding GLDA at a concentration of $5 \mathrm{mmol} \mathrm{kg}{ }^{-1}$. Compared to no addition of chelating agents, a remarkable change in biomass was not observed by adding biodegradable chelating agents (Table S2). However, among the three types of chelating agents, the toxicity for Taraxacum officinale was found to be strong by adding high concentrations of GLDA.

As shown by the above-mentioned results, it is important to select proper chelating agents at a moderate concentration for phytoremediation. In addition, it should also be noted that chelating agents generally have high stability constant and lower selectivity with any metals.

\subsubsection{Investigation. of the Metal Distribution on the Plant Surface by SEM-EDS}

SEM and element mapping images of the roots and shoots in Taraxacum officinale with no addition of a chelating agent are shown in Figure 6a,b, respectively, and those after adding EDDS at a concentration of $5 \mathrm{mmol} \mathrm{kg}^{-1}$ are shown in Figure 7 . Comparing the SEM and element mapping images between Figures 6 and 7, it is indicated that the metals were more adequately adsorbed onto the surface of the plant after adding EDDS. Singh et al. [44] reported that toxic metals for plants, such as Al, are typical hard metal ions (i.e., hard acids) which much prefer the O-donor ligands (i.e., hard bases) included in the cell wall, and remain in the cell wall without being taken into the cytoplasm. Therefore, as per the report from Singh et al., in this study, it was concluded that highly toxic elements such as $\mathrm{Al}, \mathrm{Bi}, \mathrm{Cd}$, and $\mathrm{Pb}$ were distributed much more on the surface of the shoots and roots, whereas the distribution of $\mathrm{Zn}$ on the surface of the shoots and roots was lower, since $\mathrm{Zn}$ is an essential element for metabolism in the plant [45]. I have checked that they are correct.
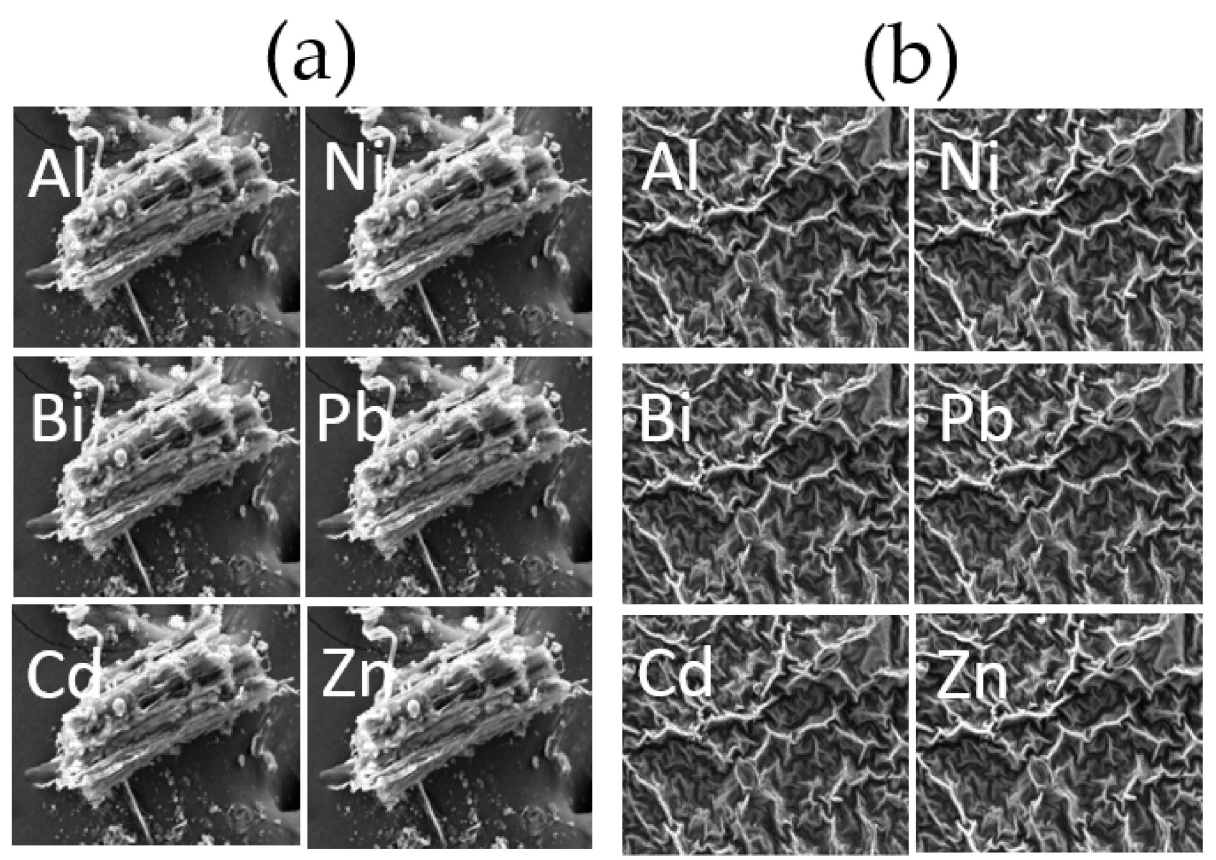

Figure 6. SEM and element mapping image of the (a) roots and (b) shoots in Taracum officinale (no chelating agent). 
(a)
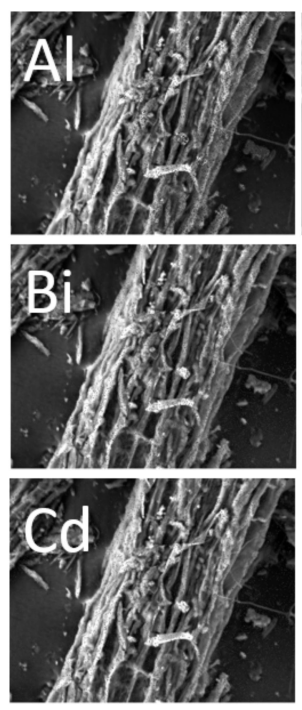
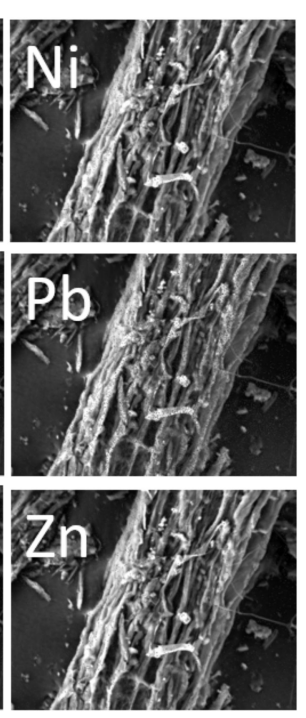

(b)
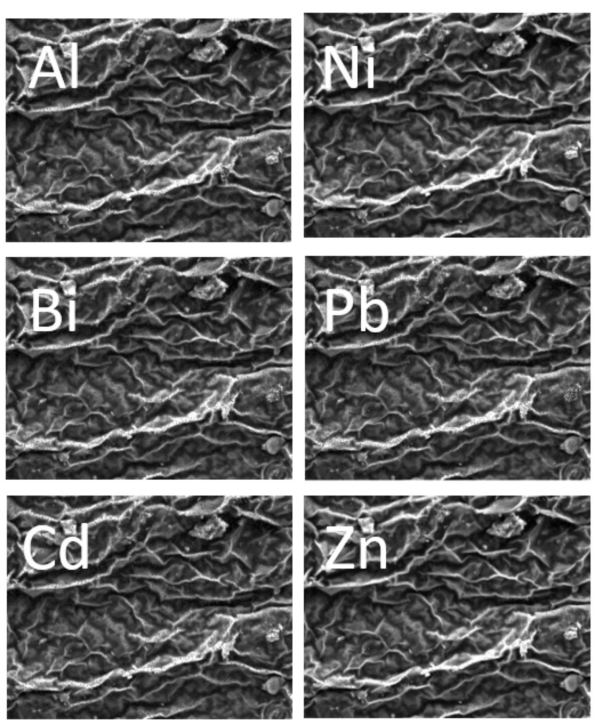

Figure 7. SEM and element mapping image of the (a) roots and (b) shoots in Taracum officinale. (EDDS at a concentration of $5 \mathrm{mmol} \mathrm{kg}^{-1}$ ).

\subsection{Phytoremediation of $\mathrm{Cd}$ and $\mathrm{Zn}$ by Gazania}

\subsubsection{Effect of EDDS on the Adsorption of $\mathrm{Cd}$ and $\mathrm{Zn}$}

The concentration of $\mathrm{Cd}$ and $\mathrm{Zn}$ in the shoots or roots of Gazania (mg/kg plant) in all of the pots by adding various concentrations of EDDS after 3 weeks of growth are shown in Figure $8 \mathrm{a}, \mathrm{b}$ (70\% humidity) and Figure S4a,b (50\% humidity). The TF of Cd and Zn in Gazania are shown in Figure S5.

With an increase in EDDS concentration, the uptake of $\mathrm{Cd}$ generally tended to increase (Figure 8a); however, a significant increase in the TF was not observed, except when adding $5 \mathrm{mmol} \mathrm{kg}{ }^{-1}$ of EDDS under $70 \%$ relative humidity conditions (Figure S5a). That is to say, it may be difficult to translocate $\mathrm{Cd}$ from the roots to shoots by Gazania, even when adding EDDS. In the case of $\mathrm{Zn}$, a distinct effect was not observed by adding EDDS compared to the case of no addition.
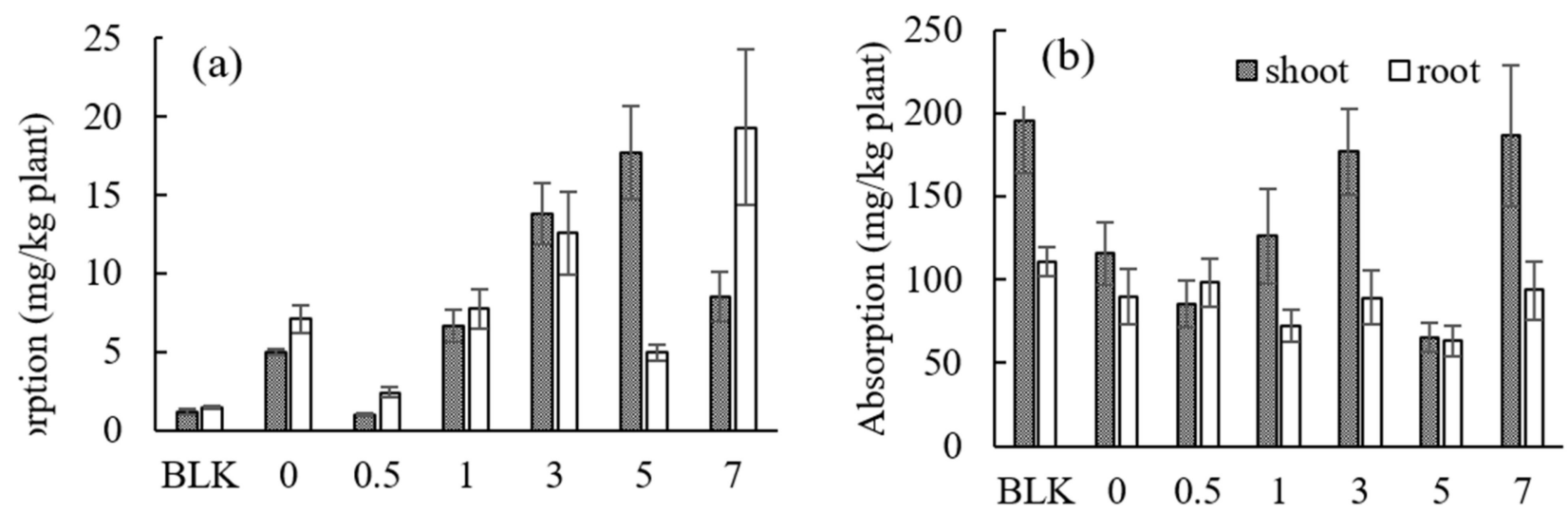

Figure 8. Effect of the EDDS concentration on the absorption of (a) $\mathrm{Cd}$ and (b) Zn by Gazania (70\% humidity). BLK represents the pot for no addition of heavy metals (i.e., $\mathrm{Cd}$ and $\mathrm{Zn}$ ) as well as no addition of EDDS (i.e., Pot No. 1 in Table 1).

Compared to the case of Taraxacum officinale under the condition of no addition of EDDS (i.e., Pot Nos. 1 and 2 in Table 1), a decrease in biomass in Gazania was relatively outstanding when adding $\mathrm{Cd}$ and $\mathrm{Zn}$, because a remarkable decrease in biomass was found in Pot No. 2 compared to Pot No. 1, as shown in Table S3 (and in contrast to the 
biomass of Taraxacum officinale not having greatly changed between Pot Nos. 1 and 2 in Table S2). This suggests that Gazania has a low tolerance against Cd and Zn; however, the plant may be adequately tolerant against EDDS, because the biomass of each shoot or root was not remarkably changed upon the addition of EDDS (judging from the data of Pot Nos. 2 and 3-7 in Table S4). Even if both Taraxacum officinale and Gazania are the same Asteraceae plants, it was found that their tolerance against chelating agents or heavy metals was considerably different.

Looking at the results from the experiments above, there is not so large selectivity, although EDDS has a higher stability constant with $\mathrm{Zn}^{2+}$ compare to $\mathrm{Cd}^{2+}$ (unlike the case of stability constant for EDTA).

\subsubsection{Effect of Other Competitive Metals on the Adsorption of $\mathrm{Cd}$ and $\mathrm{Zn}$}

The concentrations of $\mathrm{Cd}$ and $\mathrm{Zn}$ in the shoots or roots of Gazania under the presence of other competitive metals (i.e., $\mathrm{Al}, \mathrm{Pb}, \mathrm{Bi}$, and $\mathrm{Ni}$ ) by adding various concentrations of EDDS are shown in Figure 9a for $\mathrm{Cd}$ and Figure $9 \mathrm{~b}$ for $\mathrm{Zn}$. The uptake of $\mathrm{Cd}$ and $\mathrm{Zn}$ in the shoots was smaller when adding EDDS than in the case of no addition, although the uptake into the roots almost rose by adding EDDS. This insufficient uptake in the shoots may be attributed to completive uptake by the other competitive metals (i.e., $\mathrm{Al}, \mathrm{Pb}, \mathrm{Bi}$, and $\mathrm{Ni}$ ). The biomass of each shoot or root was not remarkably changed by adding EDDS under the presence of other competitive metals (Table S4).
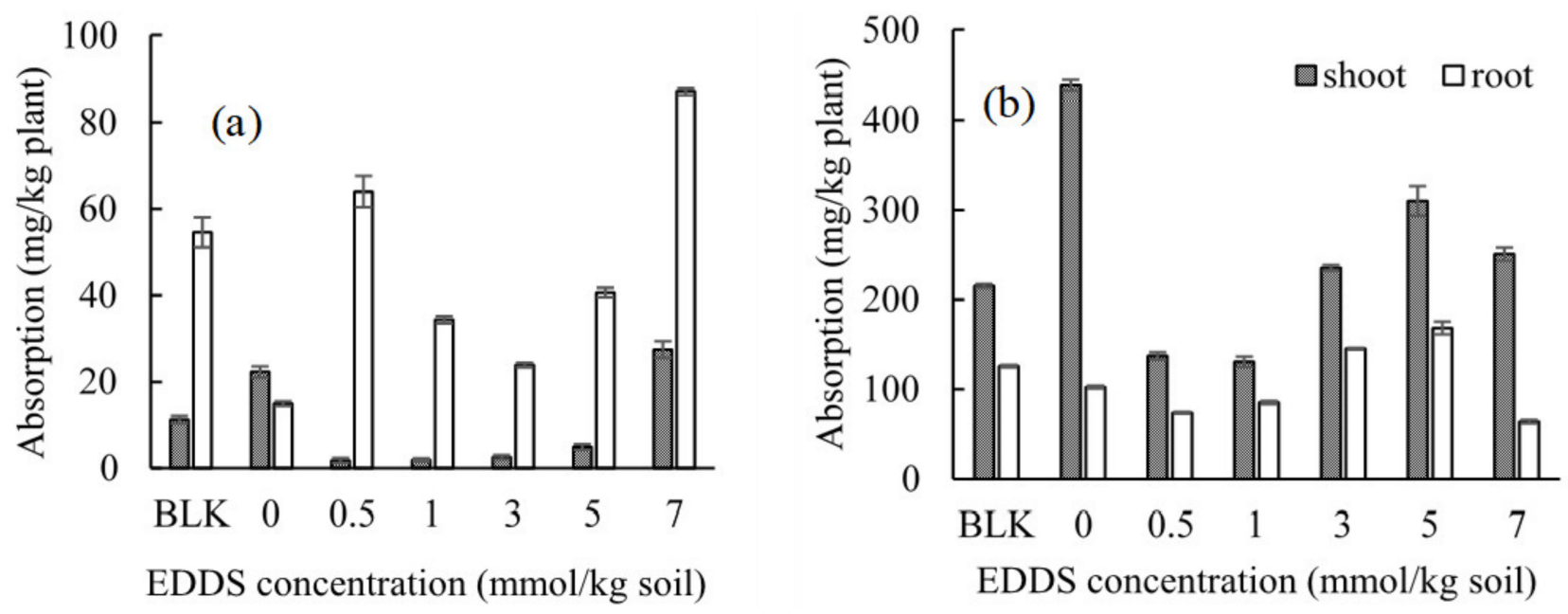

Figure 9. Effect of the EDDS concentration on the absorption of (a) $\mathrm{Cd}$ and (b) $\mathrm{Zn}$ in Gazania under the presence of $\mathrm{Al}$, $\mathrm{Bi}$, $\mathrm{Ni}$, and $\mathrm{Pb}$. BLK represents the pot for no addition of heavy metals (i.e., $\mathrm{Al}, \mathrm{Pb}, \mathrm{Bi}$, and $\mathrm{Ni}$ ) as well as no addition of EDDS (i.e., Pot No. 1 in Table 2).

\subsubsection{Effect of Chelating Agent on the Adsorption of $\mathrm{Cd}$ and $\mathrm{Zn}$}

The concentrations of $\mathrm{Cd}$ and $\mathrm{Zn}$ in the shoots or roots of Gazania by adding three types of biodegradable chelating agents at a concentration of 1 or $5 \mathrm{mmol} \mathrm{kg}^{-1}$ are shown in Figure 10a for Cd and Figure 10b for Zn.

Unlike when using Taraxacum officinale, a dosage of HIDS or GLDA was more effective as a chelating agent than EDDS for the uptake of Cd in Gazania. However, it may be difficult to translocate $\mathrm{Cd}$ into the shoots using any chelating agent by Gazania, because the concentration of $\mathrm{Cd}$ in the roots is larger than that in the shoots. In terms of $\mathrm{Zn}$, a moderate effect was observed for the uptake into the shoots by adding these chelating agents, although a significant increase was not detected. The biomass of each shoot or root in Gazania did not decrease with the addition of these biodegradable chelating agents, suggesting that the plant may be tolerant against chelating agents.

In addition, it is considered that these biodegradable chelating agents had also enhanced the mobility of metal ions from the soil due to the formation of complexes. In other 
words, we made an inference that these ligands have high metal ion binding abilities too.

This has already suggested at the end of Section 3.1.1.
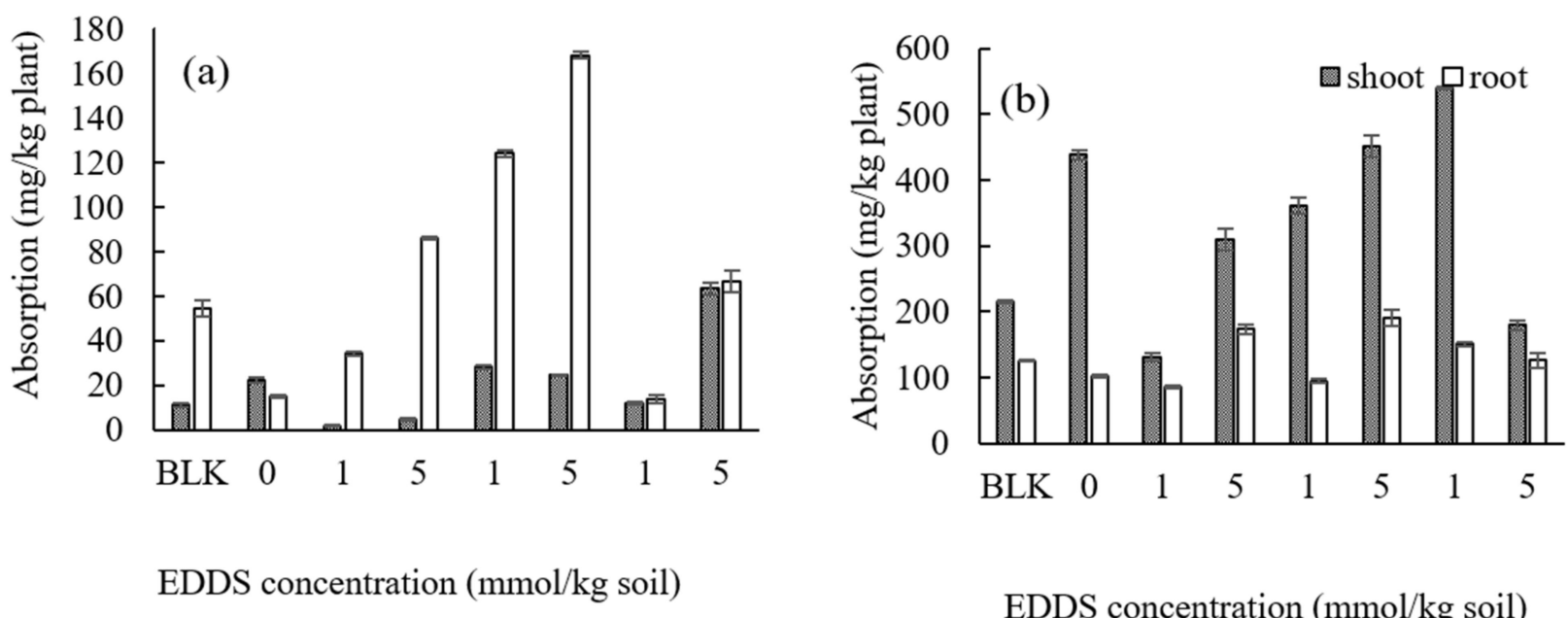

EDDS concentration ( $\mathrm{mmol} / \mathrm{kg}$ soil)

Figure 10. Effect of types and concentrations of chelating agents on the absorption of (a) Cd and (b) Zn in Gazania. BLK represents the pot for no addition of heavy metals (i.e., $\mathrm{Al}, \mathrm{Pb}, \mathrm{Bi}$, and $\mathrm{Ni}$ ) as well as no addition of chelating agents (i.e., Pot No. 1 in Table S2).

\subsection{Results of ANOVA}

The numerical results of the ANOVA for the treatments shown in Tables 1-3 are shown in panel (a) $F$ and $F_{c r i t}$ and panel (b) $p$-value. The abscissa of Figure 11 (condition) is explained in Table S5. The number of replicates was 3. If

$$
F<F_{\text {crit }}
$$

or, if $p$-value, $p$, satisfies

$$
p>\alpha
$$

where in the present case,

$$
\alpha=0.05
$$

the null hypothesis was accepted. As such, the null hypotheses were accepted for all of the cases in Figure 11 and Table S5 in either case of Equation (2) or Equation (3). This means that there were no significant differences among Pot Nos. 1-7 in Table 1 or Table 2 or among Pot Nos. 1-8 in Table 3.

Figure $\mathrm{S} 6$ shows statistical significance of differences between group means according to Pot Nos. (Groups). One can see that one cannot be sure that the difference between means is statistically significant when standard error bars overlap much, e.g., panels (a), (g), (i), (k), (l), and (n) of Figure S6. This is consistent with the fact that p-values are 0.899, 0.868, $0.943,0.960,0.950$, and 0.915 for panels (a), (g), (i), (k), (l), and (n) of Figure S6, respectively, which are large values. On the other hand, even though the error bars do no overlap so much in panels (b), (c), (d), (e), (f), (h), (j), (m), and (o), the differences are not statistically significant, whose p-values are $0.339,0.336,0.456,0.269,0.495,0.611,0.569,0.333$, and 0.386 , respectively. 


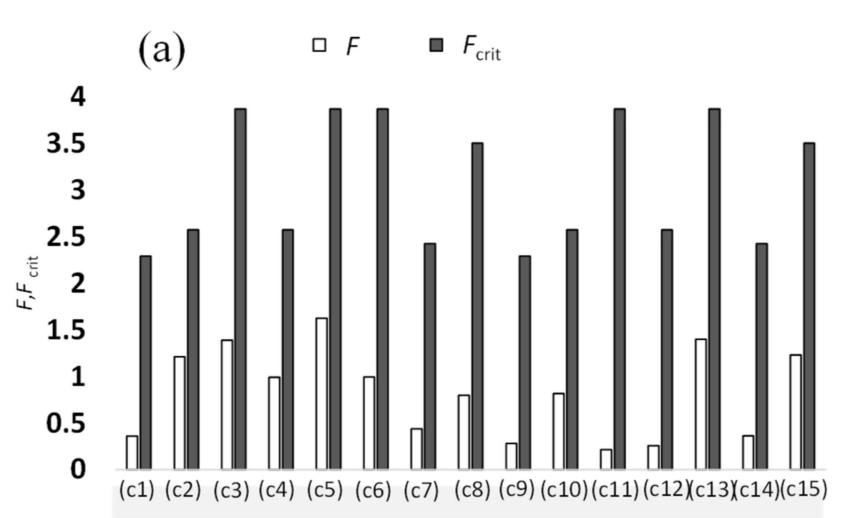

(b)

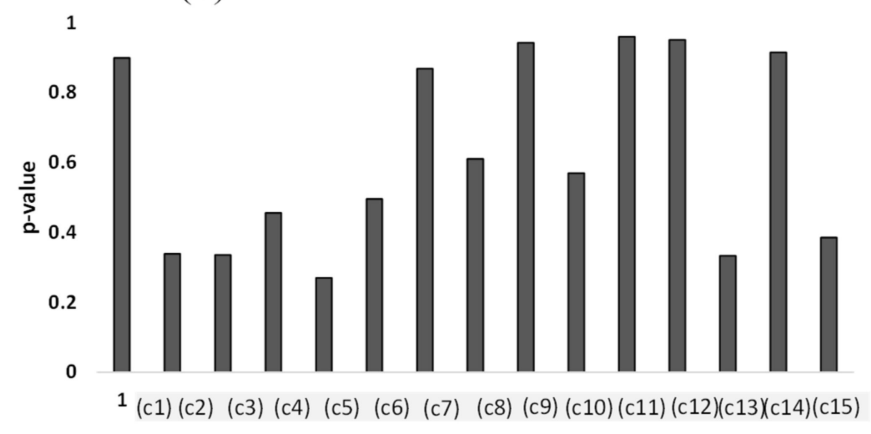

Figure 11. The numerical results of the ANOVA for the treatments shown in Tables 1-3 of (a) $F$ and $F_{\text {crit }}$ and (b) $p$-value.

\subsection{Extraction of $C d$ and $\mathrm{Zn}$ from Gazania after Phytoremediation}

\subsubsection{Effect of the Extractant Solvent on the Extraction of Cd and Zn from Gazania}

For the effective reuse of absorbent materials, an extraction experiment of $\mathrm{Cd}$ and $\mathrm{Zn}$ from Gazania after phytoremediation was conducted. The amounts of $\mathrm{Cd}$ and $\mathrm{Zn}$ extracted from the exhausted plants by using acetic acid $\left(\mathrm{CH}_{3} \mathrm{COOH}\right)$, nitric acid $\left(\mathrm{HNO}_{3}\right)$, sulfuric acid $\left(\mathrm{H}_{2} \mathrm{SO}_{4}\right)$, phosphoric acid $\left(\mathrm{H}_{3} \mathrm{PO}_{4}\right)$, aqueous ammonia $\left(\mathrm{NH}_{3}\right)$, and sodium hydroxide solution $(\mathrm{NaOH})$ are shown in Figure 12. In Figure 12, the extraction by $\mathrm{HNO}_{3}$ shows the best extraction efficiency for $\mathrm{Cd}$, while $\mathrm{H}_{2} \mathrm{SO}_{4}$ was most effective for $\mathrm{Zn}$, although $\mathrm{HNO}_{3}$ was also good. Furthermore, the extraction efficiency of the acid solvent was larger than that of the base solvent, regardless of the concentrations, which may be related to the differences in the solubility of the metal salts. In addition, it was found that a low concentration of $0.18 \mathrm{~mol} / \mathrm{L}$ was more effective in terms of extraction efficiency than $3.6 \mathrm{~mol} / \mathrm{L}$ solvent for both $\mathrm{Cd}$ and $\mathrm{Zn}$. Thus, we used a concentration of $0.18 \mathrm{~mol} / \mathrm{L}$; for example, $0.18 \mathrm{~mol} / \mathrm{L}$ nitric acid showed more effective extraction efficiency than $3.6 \mathrm{~mol} / \mathrm{L}$ of solvent for both $\mathrm{Cd}$ and $\mathrm{Zn}$. Therefore, we regarded $0.18 \mathrm{~mol} / \mathrm{L}$ nitric acid as the most appropriate extraction solvent of metal from Gazania.

\subsubsection{Extraction Experiment Using Incineration Ash from Gazania}

Based on the results in Section 3.2.1, nitric acid at a concentration of $0.18 \mathrm{~mol} / \mathrm{L}$ was selected for the extraction of $\mathrm{Cd}$ and $\mathrm{Zn}$ from the incineration ash of Gazania. The amounts of $\mathrm{Cd}$ and $\mathrm{Zn}$ extracted from the incineration ash of Gazania are shown in Figure 13. As can be seen in Figure 13, the higher the carbonization temperature, the larger the amounts of heavy metals ( $\mathrm{Cd}$ and $\mathrm{Zn}$ ) extracted. In the case of a carbonization temperature of $600{ }^{\circ} \mathrm{C}$, the amount remarkably increased 5.0 times for $\mathrm{Zn}$ and 2.3 times for $\mathrm{Cd}$ in comparison to no incineration plant. It is known that the specific surface area increases with the rise of carbonization temperature; therefore, the extraction amount may increase because the solvent becomes easy to penetrate into the ash with an increase in the specific surface area. 


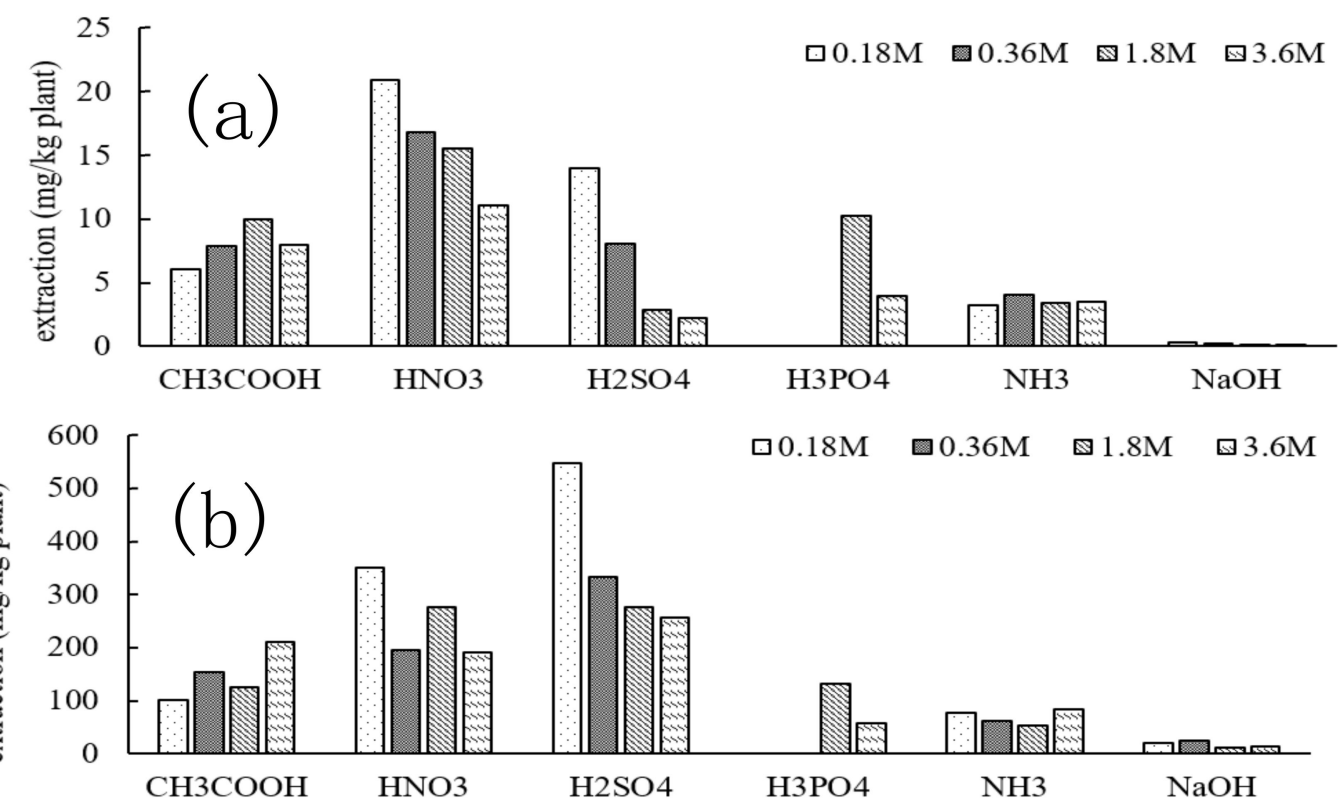

Figure 12. Effect of the solvent on the extraction of (a) Cd and (b) Zn from Gazania after phytoremediation.

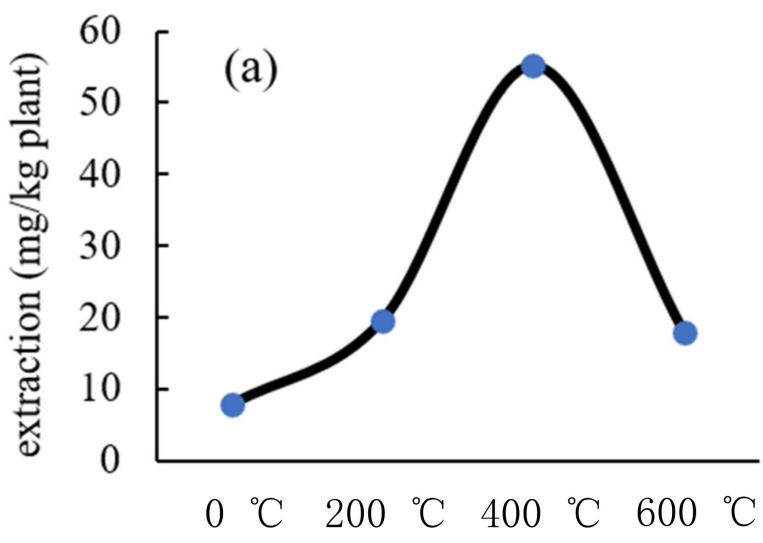

carbonization temperature $\left({ }^{\circ} \mathrm{C}\right)$

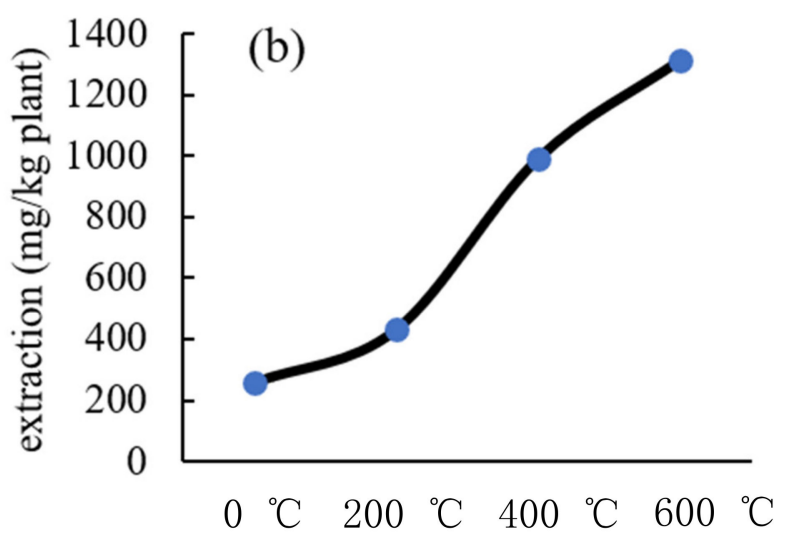

carbonization temperature $\left({ }^{\circ} \mathrm{C}\right)$

Figure 13. Effect of the carbonization temperature on the extraction of (a) Cd and (b) Zn from the incineration ash of Gazania.

From the above-mentioned results, it is revealed that metals can be efficiently extracted from plants by carbonizing said plants and that the effective utilization of the plant including metals for a future search of the utilization of metal resources should be expected.

\section{Conclusions}

In this study, phytoremediation enhanced by biodegradable chelating agents using Taraxacum officinale and Gazania for $\mathrm{Cd}$ and $\mathrm{Zn}$ was investigated. The amount of $\mathrm{Cd}$ uptaken generally increased with the increasing concentration of EDDS in Taraxacum officinale, and $\mathrm{Cd}$ and $\mathrm{Zn}$ could be removed even under the presence of other heavy metals in this plant. By adding a chelating agent, the amount of $\mathrm{Cd}$ and $\mathrm{Zn}$ absorbed by the shoots generally increased. It is suggested that Taraxacum officinale is rather tolerant against low concentrations of EDDS, as well as against heavy metals (Cd and Zn). Based on the SEMEDS analysis, it was concluded that highly toxic elements such as $\mathrm{Al}, \mathrm{Bi}, \mathrm{Cd}$, and $\mathrm{Pb}$ were distributed much on the surface of the shoots and roots, whereas the distribution of $\mathrm{Zn}$ on the surface of the shoots and roots was lower, since $\mathrm{Zn}$ is an essential element for metabolism in plants. In the case of Gazania, it was observed to be difficult to translocate $\mathrm{Cd}$ from the roots to shoots when EDDS is added, as the concentration of $\mathrm{Zn}$ was higher in 
the shoots than that in the roots. Gazania has low tolerance against $\mathrm{Cd}$ and $\mathrm{Zn}$, although it has adequate tolerance against EDDS. As such, Taraxacum officinale is more suitable for the phytoremediation of cadmium than Gazania. Our experimental treatments employed in this work were found not to be statistically different by the one-way ANOVAs, meaning that at least two of pot experiments conditions were not so different from one another. Therefore, it may be assumed that the kinds and amounts of biodegradable chelating agents added into each pot did not have such a big influence on the concentration of $\mathrm{Cd}$ and $\mathrm{Zn}$ and/or the biomass in plants (Taraxacum officinale and Gazania) under our experimental conditions.

For the effective reuse of absorbent materials, the extraction experiment of $\mathrm{Cd}$ and $\mathrm{Zn}$ from Gazania after phytoremediation was investigated, showing that $\mathrm{Cd}$ and $\mathrm{Zn}$ could be extracted well from the plants by using a low concentration of nitric acid. Using the incineration ash of the plants by carbonization was shown to be more effective for the extraction of $\mathrm{Cd}$ and $\mathrm{Zn}$.

From this work, it is suggested that the biodegradable chelating agents used in this study form stable complex with heavy metal ions and promote the dissolution of these ions to the soil solution. In addition, it can be stated that the two types of plants (Taraxacum Officinale and Gazania) used in this research provided passable results in phytoremediation.

Supplementary Materials: The following are available online at https:/ / www.mdpi.com/2076-341 7/11/4/1557/s1, Table S1: Operating conditions of ICP-MS. Table S2: Biomass of Taracum officinale. Table S3: Stability constant of EDTA and EDDS $\left(20-25^{\circ} \mathrm{C}, \mathrm{pH} 10\right)$ in common logarithm. Table S4: Biomass of Gazania. Table S5. Conditions of the ANOVA, (c1 c15), shown in Figure 11. Figure S1: Effect of the EDDS concentration on the adsorption of (a) Cd and (b) Zn by Taracum officinale (50\% humidity). BLK represents the pot for no addition of heavy metals (i.e., $\mathrm{Cd}$ and $\mathrm{Zn}$ ) as well as no addition of EDDS (i.e., Pot No. 1 in Table 1). Figure S2: Effect of the EDDS concentration on the translocation factors (TFs) of $\mathrm{Cd}$ and $\mathrm{Zn}$ in Taracum officinale (50\% humidity). BLK represents the pot for no addition of heavy metals (i.e., $\mathrm{Cd}$ and $\mathrm{Zn}$ ) as well as no addition of EDDS (i.e., Pot No. 1 in Table 1). Figure S3. Effect of the EDDS concentration on the TF in Taracum officinale under the presence of $\mathrm{Al}, \mathrm{Bi}, \mathrm{Ni}$, and $\mathrm{Pb}$. BLK represents the pot for no addition of heavy metals (i.e., $\mathrm{Al}, \mathrm{Pb}$, $\mathrm{Bi}$, and Ni) as well as no addition of EDDS (i.e., Pot No. 1 in Table 2). Figure S4. Effect of the EDDS concentration on the absorption of (a) $\mathrm{Cd}$ and (b) $\mathrm{Zn}$ by Gazania (50\% humidity). BLK represents the pot for no addition of heavy metals (i.e., $\mathrm{Cd}$ and $\mathrm{Zn}$ ) as well as no addition of EDDS (i.e., Pot No. 1 in Table 1). Figure S5. Effect of the EDDS concentration on the TF in Gazania: (a) Humidity of $70 \%$; (b) humidity of $50 \%$. BLK represents the pot for no addition of heavy metals (i.e., Cd and $\mathrm{Zn}$ ) as well as no addition of EDDS (i.e., Pot No. 1 in Table 1). Figure S6. Statistical significance of differences (one-way ANOVA, see Table S5) between group means according to Pot Nos. (Groups). The panel numbers, (a-o) correspond to the conditions, (c1-c15) of Table S5, respectively. The box is IQR (interquartile range), the cross is the mean, the bar is second quartile, the top of the bar is maximum, and the bottom of the bar is minimum.

Author Contributions: Conceptualization, supervision, data evaluation, and writing, N.K.; experiments and data analysis, T.H.; measurements of SEM-EDS and investigation of the literature, H.Z.; ICP-MS measurements and figures and table construction, N.M.; experiments and investigation of the literature, D.E.V.A.; statistical analysis (ANOVA), K.M. All authors have read and agreed to the published version of the manuscript.

Funding: The present work was partially supported by a fund for the promotion of Niigata University KAAB Projects from the Ministry of Education, Culture, Sports, Science, and Technology, Japan.

Institutional Review Board Statement: Not applicable.

Informed Consent Statement: Not applicable.

Data Availability Statement: The data presented in this study are available on request from the corresponding author. The data are not publicly available due to their originality.

Acknowledgments: The authors are grateful to. Ohizumi of the Office for Environment and Safety in Niigata University, as well as T. Nomoto and T. Tanaka of the Faculty of Engineering in Niigata University for permitting the use of ICP-MS and SEM and for providing helpful advice regarding the measurements. 
Conflicts of Interest: The authors declare no conflict of interest.

\section{References}

1. Lim, J.-M.; Salidol, A.L.; Butcher, D.J. Phytoremediation of lead using Indian mustard (Brassica juncea) with EDTA and electrodics. Microchem. J. 2004, 76, 3-9. [CrossRef]

2. Lasat, M.M. Phytoextraction of toxic metals. J. Environ. Qual. 2002, 31, 109-120. [PubMed]

3. Lin, C.; Liu, J.; Liu, L.; Zhu, T.; Sheng, L.; Wang, D. Soil amendment application frequency contributes to phytoextraction of lead by sunflower at different nutrient levels. Environ. Exp. Bot. 2009, 65, 410-416. [CrossRef]

4. Ma, Y.; Prasad, M.N.V.; Rajkumar, M.; Freitas, H. Plant growth promoting rhizobacteria and endophytes accelerate phytoremediation of metalliferous soils. Biotechnol. Adv. 2011, 29, 248-258. [CrossRef]

5. Rascio, N.; Navari-Izzo, F. Heavy metal hyperaccumulating plants: How and why do they do it? And what makes them so interesting? Plant. Sci. 2011, 180, 169-181. [CrossRef] [PubMed]

6. Pal, P.; Pal, A. Surfactant-modified chitosan beads for cadmium ion adsorption. Int. J. Biol. Macromol. 2017, 104, 1548-1555. [CrossRef]

7. Pal, P.; Pal, A. Treatment of real wastewater: Kinetic and thermodynamic aspects of cadmium adsorption onto surfactant-modified chitosan beads. Int. J. Biol. Macromol. 2019, 131, 1092-1100. [CrossRef]

8. Ades, A.E.; Kazantzis, G. Lung cancer in a non-ferrous smelter: The role of cadmium. Br. J. Ind. Med. 1988, 45, 435-442. [CrossRef]

9. Bernard, A. Cadmium \& its adverse effects on human health. Indian J. Med. Res. 2008, 128, 557-564.

10. Lombi, E.; Zhao, F.-J.; Dunham, S.J.; McGrath, S.P. Phytoremediation of heavy metal-contaminated soils. J. Environ. Qual. 2001, 30, 1919-1926. [CrossRef]

11. Wu, L.H.; Luo, Y.M.; Xing, X.R.; Christie, P. EDTA-enhanced phytoremediation of heavy metal contaminated soil with Indian mustard and associated potential leaching risk. Agric. Ecosyst. Environ. 2004, 102, 307-318. [CrossRef]

12. Gupta, A.K.; Sinha, S. Role of Brassica juncea (L.) Czern. (var. Vaibhav) in the phytoextraction of Ni from soil amended with fly ash: Selection of extractant for metal bioavailability. J. Hazard. Mater. 2006, 136, 371-378. [PubMed]

13. Watanabe, K.; Sasaya, K. Cadmium phytoremediation and uptake of zinc and copper by Asteraceae plants-A pot experiment using cadmium enriched soil. Teikyo Univ. Sci. Bull. 2007, 3, 21-27. (In Japanese)

14. Grčman, H.; Velikonja-Bolta, Š.; Vodnik, D.; Kos, B.; Leštan, D. EDTA enhanced heavy metal phytoextraction: Metal accumulation, leaching and toxicity. Plant. Soil 2001, 235, 105-114. [CrossRef]

15. Evangelou, M.W.H.; Ebel, M.; Schaeffer, A. Chelate assisted phytoextraction of heavy metals from soil. Effect, mechanism, toxicity, and fate of chelating agents. Chemosphere 2007, 68, 989-1003. [CrossRef] [PubMed]

16. Nowack, B. Environmental chemistry of aminopolycarboxylate chelating agents. Environ. Sci. Technol. 2002, 36, 4009-4016. [CrossRef]

17. Cao, M.; Hu, Y.; Sun, Q.; Wang, L.; Chen, J.; Lu, X. Enhanced desorption of PCB and trace metal elements (Pb and Cu) from contaminated soils by saponin and EDDS mixed solution. Environ. Pollut. 2013, 174, 93-99. [CrossRef]

18. Meers, E.; Ruttens, A.; Hopgood, M.J.; Samson, D.; Tack, F.M.G. Comparison of EDTA and EDDS as potential soil amendments for enhanced phytoextraction of heavy metals. Chemosphere 2005, 58, 1011-1022. [CrossRef]

19. Wang, A.; Luo, C.; Yang, R.; Chen, Y.; Shen, Z.; Li, X. Metal leaching along soil profiles after the EDDS application—A field study. Environ. Pollut. 2012, 164, 204-210. [CrossRef]

20. Salt, D.E.; Blaylock, M.; Kumar, N.P.B.A. Phytoremediation: A novel strategy for the removal of toxic metals from the environment using plants. Nat. Biotechnol. 1995, 13, 468-474. [CrossRef]

21. Xu, Y.; Wang, Q.; Wang, H.; Peng, Y.; Xue, L. Screening of dominant plants for the treatment of heavy metal pollution in the soil around the mining area: Taking a lead-zinc smelting area in the west of Guanzhong as an example. Environ. Protect. Sci. 2016, 42, 61.

22. Hu, N.; Luo, Y.; Wu, L.; Song, J. A field lysimeter study of heavy metal movement down the profile of soils with multiple metal pollution during chelate-enhanced phytoremediation. Int. J. Phytoremediation 2007, 9, 257-268. [CrossRef] [PubMed]

23. Gao, L.; Kano, N.; Sato, Y.; Li, C.; Zhang, S.; Imaizumi, H. Behavior and distribution of heavy metals including rare Earth elements, thorium, and uranium in sludge from industry water treatment plant and recovery method of metals by biosurfactants application. Bioinorg. Chem. Appl. 2012. [CrossRef]

24. Szanto, M.; Micle, V.; Prodan, C.V. Lead extraction from soil by washing with ethylenediamine disuccinic acid tisodium salt ( $\left.\mathrm{Na}_{3} \mathrm{EDDS}\right)$. ProEnvironment 2012, 5, 184-187.

25. Hu, Y.; Quan, C.; Guo, M.; Ye, X.; Wu, Z. Facile synthesis of $\mathrm{Fe}_{3} \mathrm{O}_{4}-\mathrm{N}-[(3-$ Trimethoxysilyl)propyl]ethylenediamine triaceti-cacid trisodium salt and adsorption of $\mathrm{Sr}^{2+}$. J. Residuals. Sci. Technol. 2016, 13, S169-S174. [CrossRef]

26. Kozai, T.; Tanaka, K.; Jeong, B.R.; Fujiwara, K. Effect of relative humidity in the culture vessel on the growth and shoot elongation of Potato (Solanum tuberosum L.) plantlets in vitro. J. Jpn. Soc. Hortic. Sci. 1993, 62, 413-417. [CrossRef]

27. Nam, J.-G.; Hartt, W.H.; Kim, K.-J. Effects of relative humidity and temperature on the transport of chloride in the concrete. J. Korea. Concr. Inst. 2005, 17, 821-828. [CrossRef]

28. Niinae, M.; Nishigaki, K.; Akita, T.; Ohta, M. Effect of Fe(III) and Ca on extraction of Pb from contaminated soils with chelating agents. Resour. Proc. 2010, 57, 29-34. [CrossRef] 
29. Zheng, M.-Z.; Cai, C.; Hu, Y.; Sun, G.-X.; Williams, P.N.; Cui, H.-J.; Li, G.; Zhao, F.-J.; Zhu, Y.-G. Spatial distribution of arsenic and temporal variation of its concentration in rice. New Phytol. 2011, 189, 200-209. [CrossRef]

30. Maria, S.D.; Puschenreiter, M.; Rivelli, A.R. Cadmium accumulation and physiological response of sunflower plants to Cd during the vegetative growing cycle. Plant. Soil. Environ. 2013, 59, 254-261. [CrossRef]

31. Wang, C.-J.; Wang, J.-J.; Chiu, C.-Y.; Lai, S.-Y.; Lin, Y.-M. Transfer factors of ${ }^{90} \mathrm{Sr}$ and ${ }^{137} \mathrm{Cs}$ from soil to the sweet potato collected in Taiwan. J. Environ. Radioact. 2000, 47, 15-27. [CrossRef]

32. Microsoft ${ }^{\circ E x c e l}{ }^{\circledR 2019}$ MSO (16.0.10368.20035) 64 bit. Available online: https:/ / docs.microsoft.com/ja-jp/officeupdates/updatehistory-office-2019 (accessed on 16 November 2020).

33. Luo, J.; Cai, L.; Qi, S.; Wu, J.; Sophie Gu, X.W. Improvement effects of cytokinin on EDTA assisted phytoremediation and the associated environmental risks. Chemosphere 2017, 185, 386-393. [CrossRef] [PubMed]

34. Wang, S.; Zhao, Y.; Guo, J.; Zhou, L. Effects of Cd, Cu and Zn on Ricinus communis L. growth in single element or co-contaminated soils: Pot experiments. Ecol. Eng. 2016, 90, 347-351. [CrossRef]

35. Wang, Y.; Wang, X.; Wang, C.; Wang, R.; Peng, F.; Xiao, X.; Zeng, J.; Fan, X.; Kang, H.; Sha, L.; et al. Proteomic profiling of the interactions of $\mathrm{Cd} / \mathrm{Zn}$ in the roots of dwarf polish wheat (Triticum polonicum L.). Front. Plant Sci. 2016, 7, 1378. [CrossRef] [PubMed]

36. Sinclair, A.S.; Krämer, U. The Zinc Homeostasis Network of Land Plants. BBA Mol. Cell. Res. 2012, 9, 1553-1567. [CrossRef]

37. Wyszkowska, J.; Borowik, A.; Kucharski, M.; Kucharski, J. Effect of Cadmium, Copper and Zinc on Plants, Soil Microorganisms and Soil Enzymes. J. Elem. 2013, 18, 769-796. [CrossRef]

38. Ike, M.; Hirata, K. Environmental Conservation and Remediation Technologies Utilizing Great Potential of Plants: Extremely Ecological and Nature-Friendly Systems for Saving the Earth; CMC Publishing Co.: Tokyo, Japan, 2011; pp. 77-79.

39. Kayser, A.; Wenger, K.; Keller, A.; Attinger, W.; Felix, H.R.; Gupta, S.K.; Schulin, R. Enhancement of phytoextraction of Zn, Cd, and $\mathrm{Cu}$ from calcareous soil: The use of NTA and sulfur amendments. Environ. Sci. Technol. 2000, 34, 1778-1783. [CrossRef]

40. Li, T.; Di, Z.; Yang, X.; Sparks, D.L. Effects of dissolved organic matter from the rhizosphere of the hyperaccumulator sedum alfredii on sorption of zinc and cadmium by different soils. J. Hazard. Mater. 2011, 192, 1616-1622. [CrossRef]

41. Imura, H.; Hinoue, T. (Eds.) Basics of Analytical Chemistry; Kagaku-Dojin Publishing Co.: Kyoto, Japan, 2015 ; p. 216.

42. Wirosoedarmo, R.; Anugroho, F.; Hanggara, S.D.; Gustinasari, K. Effect of adding chelating agents on the absorption of zinc from polluted soil sludge textile industrial waste by sunflower plant (Helianthus annuus L.). Appl. Environ. Soil. Sci. 2018. [CrossRef]

43. Dipu, S.; Kumar, A.A.; Thanga, S.G. Effect of chelating agents in phytoremediation of heavy metals. Remediation 2012, 22, 133-146. [CrossRef]

44. Singh, S.; Tripathi, D.K.; Singh, S.; Sharma, S.; Dubey, N.K.; Chauhan, D.K.; Vaculík, M. Toxicity of aluminium on various levels of plant cells and organism: A review. Environ. Exp. Bot. 2017, 137, 177-193. [CrossRef]

45. White, P.J.; Whiting, S.N.; Baker, A.J.M.; Broadley, M.R. Dose zinc move apoplectically to the xylem in roots of Thlaspi caerulescens? New Phytol. 2002, 153, 201-207. [CrossRef] 